\title{
Contextual Learning And Learning Effectiveness Based On Problems With Learning Results Under The Neonatal Baby And Toddlers Care in Sari Mulia Midwifery Academy banjarmasin
}

Rizky Vaira ${ }^{1} *$

*vairarizky@gmail.com

${ }^{1}$ Abdi Persada Academy of Midwifery, Banjarmasin, Indonesia

Adriana Palimbo ${ }^{2}$

${ }^{2}$ STIKES Sari Mulia, Banjarmasin, Indonesia

Adriana_palimbo@stikessarimulia.ac.id

Susanti Suhartati ${ }^{2}$

${ }^{2}$ STIKES Sari Mulia, Banjarmasin, Indonesia

Susanti_suhartati@stikessarimulia.ac.id

\begin{abstract}
Objective : To analyze the effectiveness of Contextual Teaching Learning (CTL) and Problem Based Learning (PBL) in improving learning outcomes and learning activities on the subjects of Neonates, Infant and Toddler Care

Method : This study method used experimental design with Pretest-Posttest Randomized Comparison Group Design. CTL sample is 15 people, and PBL sample is 15 people. Data value of the pre-test and post test was conducted by Shapiro Wilk normality test and homogeneity test with levene's test analysis with paired samples t-test and independent sample t-test with a confidence level of $95 \%$.

Results : Data value of the pre-test and post-test with normal distribution and homogeneous. 1) The results of learned PBL and CTL have significant differences, of which $p=0.000>\alpha=0.05$. 2) Ngain score of PBL in the high category, while CTL in the medium category. 3) The effectiveness of PBL is 42.32 and effectiveness of the CTL is 36.6; 4) Complete class classical PBL $100 \% \geq 85 \%$, CTL grade $73 \%<85 \%$. 5) Learned activities PBL $80 \%$ highly effective and learned activities CTL $60 \%$ effective.
\end{abstract}

Conclusion : CTL and PBL have effectiveness in improving learning outcomes.

Keywords : CTL, PBL, effectiveness, results learning.

\section{INTRODUCTION}

After the issuance of KKNI, it encourages all universities to adapt to the provisions in it. KKNI is a statement of Indonesian human resource quality, where its qualification benchmarks are determined based on learning outcomes [1].

Based on the Regulation of the Minister of Technology Research and Higher Education No. 44 of 2015 on National Standards of Higher Education (SN-DIKTI) encourages all education providers in
Indonesia to be able to adjust their curriculum changes with reference to the source of the law so that the resulting competence qualification can be integrated between education and the field of job training and work competence [2].

Sari Mulia Midwifery Academy is one of the diploma III midwifery education that currently uses KKNI-based Higher Education Curriculum. The Diploma III program must be able to solve work problems with the nature and context in accordance with the 
field of applied expertise, based on logical and innovative thinking, independently in both the implementation and the job responsibilities.

Learning method Contextual Teaching Learning (CTL) is where learners can construction knowledge owned on the reality of everyday life and learning methods Problem Based Learning (PBL) is where learners practice to solve problems. Problemsolving learning becomes very important in training learners to become more skilled, knowledgeable, as well as having cognitive, affective, and psychomotor abilities [3].

Researchers also conducted interviews to 10 students of second grade 3 semester at Academy of Midwifery Sari Mulia Banjarmasin with the results of most of the students said the teaching methods conducted during this more lecture and question and answer or method of Teacher Centered Learning (TCL). Students also said that the lecturers have done the learning by dividing the students into several groups consisting of 10 people and even more to do the tasks so that less effective learning.

Based on the research of Desi Kumala (2012) which has been done in one of Midwifery Academy in Central Kalimantan, with student background get bored on method of discussion study because only dominated by student who like to talk. So that researchers do learning with the method of collaborative learning and obtained the result that there is an increase in learning outcomes.

This is the reason why researchers make Sari Mulia Midwifery Academy as a place of research. The research material used by the researcher is Neonatus Midwifery Course because it is in accordance with the application of the model to be experimented. Researchers chose the learning model of CTL and PBL because according to the Ministry of Education and Culture (2014) in accordance with the objective of KKNI in producing graduate profile according to SNPT.
The objective of this study was to analyze effectiveness of Contextual Teaching Learning (CTL) and Problem Based Learning (PBL) with Learning Outcomes of Neonates Infants and Toddlers Undergraduate Courses at Sari Mulia Banjarmasin Midwifery Academy.

\section{METHODS}

In this research used true experimental with Randomized Pretest-Posttest Comparison Group Design. The selection of randomized pretest-posttest comparison group design is due to both the CTL and PBL groups being selected randomly and the following is the design design of the study:

Table 1. Research Design
\begin{tabular}{lll}
$\mathrm{P}_{1}$ & $\mathrm{X}_{1}$ & $\mathrm{P}_{2}$ \\
\hline $\mathrm{P}_{3}$ & $\mathrm{X}_{2}$ & $\mathrm{P}_{4}$ \\
\hline
\end{tabular}

$\mathrm{P}_{1} \quad$ : Pre test CTL class

$\mathrm{P}_{2} \quad$ : Post test CTL class

$\mathrm{P}_{3} \quad$ : Pre test PBL class

$\mathrm{P}_{4} \quad$ : Post test PBL class

$\mathrm{X}_{1} \quad$ : Learning method CTL

$\mathrm{X}_{2} \quad$ : Learning method PBL

In this study the population used is all students of the fourth semester of Midwifery Academy Sari Mulia Banjarmasin 2015/2016. The sample in this research is A student of 15 students as CTL class. The class of PBL in this research is B student of 15 students.

The research instruments used consist of: (1) Learning Implementation Plan; (2) evaluation questions for pre-test and post test; (3) student activity observation sheets of CTL and PBL class; and (4) documents. Instruments has been verification of validity test, reliability, problem difficulty level, distinguishing power, and effectiveness of spoilers. After instrument verification, it is found that the instrument is suitable for use in the research and the data obtained can describe the actual condition. 
The steps taken in data collection are: (1) preparation; (2) implementation; and (3) evaluation. At the implementation stage there are 5 observers who help to collect research data by way of observation during the learning process takes place. At the evaluation stage, the instruments that have been collected are evaluated for completeness to find out the results of the research. The techniques used in collecting data are observation, tests and documentation.

The data of cognitive learning result is obtained from the assessment of the pre test and post test questions assessed based on the scoring rubric that has been made. The maximum score of each question is 5 . The data used assayed firstly that test for normality test and homogeneity test data before analyzing test mean difference. Normality test is used to find out whether the data used in the study is normally distributed or not. Normality test used is Saphiro Wilk test. Homogeneity test is used to find out whether the population variances of both samples are the same or different. The homogeneity test in the study used Levene's Equality of Error Variances Test.

The analysis aimed to find out the effectiveness of CTL and PBL methods with learning outcomes was to use the mean difference test ( $\mathrm{t}$ test) tested at a 0.05 significance level $(\mathrm{p}<0.05)$.

\section{RESULTS}

A. Learning Outcomes and Classic completeness

Table 2. Results of Analysis of Improved Learning Outcomes of CTL and PBL

\begin{tabular}{|c|c|c|c|c|c|c|c|}
\hline \multirow{2}{*}{ Kelas } & \multicolumn{6}{|c|}{ Huruf Mutu } & $\begin{array}{l}\text { Sig. (2- } \\
\text { tailed) }\end{array}$ \\
\hline & $\mathrm{A}$ & $\%$ & B & $\%$ & $\mathrm{C}$ & $\%$ & \multirow{3}{*}{0,000} \\
\hline Post & 0 & 0 & 11 & 73,33 & 4 & 26,67 & \\
\hline $\begin{array}{l}\text { Post } \\
\text { PBL }\end{array}$ & 11 & 73,33 & 4 & 26,67 & 0 & 0 & \\
\hline
\end{tabular}

The value of Post CTL test subjects Neonatal Infant Care and Toddlers obtained $73.33 \%$ of 15 students get a quality score B and the value of PBL $73.33 \%$ post test of 15 students with quality score A. This means that learning Neonates Infant and Toddler Care using learning method Contextual Teaching Learning (CTL) and Problem Based Learning (PBL) effective in improving student learning outcomes.

Based on the result of t-test of two sample samples (independent sample t test), the probability (sig.2-tailed) <0.05, the condition shows significant difference of learning result due to CTL and PBL treatment. The effectiveness caused by the CTL and PBL models with learning outcomes appears in the change in mean values of CTL and PBL.

\begin{tabular}{|c|c|c|c|c|}
\hline & $\begin{array}{l}\text { NBL (Nilai } \\
\text { Batas } \\
\text { Lulus) }\end{array}$ & $\begin{array}{l}\text { Frekuensi } \\
\text { (n) }\end{array}$ & $\begin{array}{l}\text { Persentase } \\
(\%)\end{array}$ & $\begin{array}{l}\text { Standar } \\
\text { Ketuntasan } \\
\text { Klasikal (\%) }\end{array}$ \\
\hline \multicolumn{5}{|l|}{ PostPBL } \\
\hline & $<=69$ & 0 & 0 & \multirow{3}{*}{85} \\
\hline \multirow[t]{2}{*}{ Group 1} & \multirow[t]{2}{*}{$>69$} & 15 & 100 & \\
\hline & & \multicolumn{2}{|c|}{ Group 2} & \\
\hline \multicolumn{5}{|l|}{ Total } \\
\hline \multicolumn{5}{|l|}{ PostCTL } \\
\hline & $<=69$ & 4 & 27 & \multirow{4}{*}{85} \\
\hline \multirow[t]{2}{*}{ Group 1} & \multirow[t]{2}{*}{$>69$} & 11 & 73 & \\
\hline & & 15 & 100 & \\
\hline Group 2 & & & & \\
\hline Total & & & & \\
\hline
\end{tabular}

Based on data processing average learning outcomes PBL class of 81.00 with the percentage of completeness of classical learning achievement reached $100 \% \geq 85 \%$. The average learning outcomes of the CTL group was 71.00 with the percentage of completeness of the classical learning achievement reaching $73 \%<85 \%$.

\section{B. Level of Effectiveness and Understanding}

Based on data processing, students' understanding improvement after being given treatment for CTL class included in medium category, for CTL class included in high category. 
Table 4. Level of effectiveness of CTL and PBL

\begin{tabular}{|c|c|c|c|c|c|c|}
\hline \multirow[t]{2}{*}{ No } & \multirow[t]{2}{*}{ Kelas } & \multicolumn{2}{|c|}{ Mean } & $\begin{array}{c}\text { Peningk } \\
\text { atan }\end{array}$ & $\begin{array}{l}\text { Normal } \\
\text { Gain }\end{array}$ & $\begin{array}{l}\text { Kriteria } \\
\text { faktor } \mathbf{g}\end{array}$ \\
\hline & & $\begin{array}{l}\text { Pre } \\
\text { test }\end{array}$ & $\begin{array}{l}\text { Post } \\
\text { test }\end{array}$ & $\begin{array}{l}\text { Pre test } \\
-\quad \text { Post } \\
\text { test }\end{array}$ & $\begin{array}{l}\text { Pre test - } \\
\text { Post test }\end{array}$ & $\begin{array}{l}\text { Pre test - } \\
\text { Post test }\end{array}$ \\
\hline 1 & CTL & 34,44 & 71,00 & 36,67 & 0,5 & Sedang \\
\hline 2 & PBL & 38,67 & 81,00 & 42,32 & 0,7 & Tinggi \\
\hline
\end{tabular}

Based on data processing calculation of mean value of pre test and post test then, level of effectiveness of CTL class is 36,67 and level of effectiveness of PBL class is 42,32.

Table 5. Level of understanding of CTL and PBL

\begin{tabular}{lllll}
\hline No & Kelas & \multicolumn{2}{c}{ Mean } & \multicolumn{1}{c}{ Keefektifan } \\
\cline { 3 - 5 } & & Pre test & Post test & Pre test - Post test \\
\hline 1 & CTL & 34,44 & 71,00 & 36,67 \\
\hline 2 & PBL & 38,67 & 81,00 & 42,32
\end{tabular}

Based on data processing calculation of mean value of pre test and post test then, level of effectiveness of CTL class is 36,67 and level of effectiveness of PBL class is 42,32.

\section{Learning Activities}

Table 6. Level of effectiveness of CTL and PBL

\begin{tabular}{ccccc}
\hline No & Kelas & $\begin{array}{c}\text { Frekuensi } \\
(\mathrm{n})\end{array}$ & Persentasi $(\%)$ & Kategori \\
\hline 1 & CTL & 9 & 60 & Sangat Efektif \\
\hline 2 & PBL & 12 & 80 & Cukup Efektif \\
\hline
\end{tabular}

Based on the results of data processing found that $60 \%$ CTL class is quite effective with many students 9 people and $80 \%$ PBL class is very effective with many students 12 people.

\section{DISCUSSION}

A. Learning Outcomes and Classic Ex

Based on the average score of student learning outcomes, it is known that neonatal infant and underfive learning subjects with sub subject of succenyaneum, cephal hematoma, and hypotermi through CTL method can improve learning outcomes. In accordance with the results of research Amrizaldi (2010) which shows an increase in learning outcomes after being given learning by CTL method in improving the mastery of the concept.
Based on the average score of student learning outcomes, it is known that neonatal infant and underfive learning subjects with sub subject of succenyaneum, cephal hematoma, and hypotermia through PBL method can improve learning outcomes. In accordance with the results of research Yoon, et al (2015) which shows an increase in pre post test value. The post test score to measure students' creative thinking ability is significantly higher for students in PBL classes.

Based on the results of research Neni (2015) learning methods of CTL and PBL provide effectiveness in improving learning outcomes. Through the CTL method students are able to link the material with the application in daily life and the PBL method emphasizes more on problem solving. From an unknown problem, students are required to be able to solve the problem with a different mindset of each student. The learning environment in accordance with the PBL is an open environment, using democratic processes and an active role of students. In addition, the researchers also conducted feedback activities by giving oral questions to female students and most of the students could answer the questions posed correctly. When the students' answers are correct then they are given confirmation that they are sure that the answer is correct, so that the students can find their own correct answer. This is also in line with the research of Kokom (2015) which shows the CTL method has a strong positive relationship with character development. The findings of this study explain that first, contextual learning teaches students' life skills, including principles of interdependence, differentiation, and self-regulation; secondly, encouraging the establishment of democratic learning; third, contextual learning includes elements of character development; and fourth, character 
education in helping students find and develop local moral values.[9].

\section{B. Level of Understanding and Effectiveness.}

Based on the results of $\mathrm{N}$-gain Score shows that the level of understanding of students after getting CTL treatment is in the medium category and the level of understanding of students after getting the treatment of PBL is in the high category. Furthermore, based on the increase of pre test and post test, the effectiveness of CTL method is 36.67 and the effectiveness of PBL method is 42,32 .

The results of Min Swe, et al (2015) showed that over $90 \%$ of students stated that the PBL classes helped them to develop teamwork, self-study, and problem-solving skills. Students have a positive perception on PBL learning methods and help them to develop a deep and structured scientific knowledge base. PBL learning methods can train higherorder thinking skills, so that knowledge is embedded based on student's schemata so that learning is more meaningful. It is expected that in the future the students will be able to apply in accordance with the concepts studied. In addition it is expected that students can bridge between the concepts and practice in the field by still working according to evidence based.

The results of Mikkelsen, et al (2007) showed that the CTL method can broaden the comprehension and competence of how to study individually and in groups. Linking professional knowledge (eg medical science) and knowledge improvement, and multidisciplinary team learning is essential to understanding how patient care and safety in a clinical microsystem.

Through CTL learning method, students are expected to be able to construct new knowledge about caput sucedaneum, cephal hematoma and hypothermia while in practice area. Students can diagnose and establish what action should be done and not done when providing treatment for infants who have problems such as material that has been given researchers.

\section{Learning Activities}

Based on the observation result of student activity observation activity with CTL learning method from 15 students as many as 9 students in the category is quite effective or $60 \%$, and 6 students in very effective category or $40 \%$. Based on the assessment of student activity observation sheet using PBL method of 15 students as many as 12 students in the category is very effective or $80 \%$ and 3 students in the category is quite effective or $20 \%$.

The results of EL-Nemer, et al (2009) showed that PBL is a promising learning strategy and is an interactive learning. PBL learning method is believed to advance education and career development of the future.

PBL learning method part or the whole process is by group discussion activities make students more active in the learning process. In this case, female students are given the opportunity to improve their knowledge of the material by communicating or interacting with group members and working together to solve problems.

The application of the PBL method was also put forward by Katherine (2015) that problem-based learning can develop critical and clinical thinking, decisionmaking needed for various situations encountered in practice. Students need to master the necessary knowledge and skills, but also need to assess, analyze, decide on the action, and evaluate their actions. PBL helps students to use their clinical imagination to begin to understand the nature of the clinical situation and adjust the intervention [13].

The results of the study by Brett (2006) also show that student-centered learning (SCL) and Case By Learning 
(CBL) in clinical education are an important part of prehospital education at Monash University. This pedagogy learning has facilitated a small online learning community and allows for tighter supervision of the technology of the current learning environment. This study concludes that $\mathrm{CBL}$ is a congruent learning method in the clinical curriculum for prehospital students [14].

Based on the results of previous research, it can be associated with research conducted at this time that PBL learning methods can stimulate open-mindedness and encourage learners to perform more critical and active learning. The PBL method also poses challenges to students so that they can gain satisfaction by finding new knowledge for themselves. The use of PBL learning methods makes it easier for students to understand the material because they are invited to learn through the problems that arise and how to solve the problem. Automatically students get knowledge as well as how to apply it.

Raub, et al (2015) The CTL learning model can improve students' cognitive abilities and create opportunities for them to explore the contents of contextual learning. These parameters can then be combined with a natural experience in developing knowledge if implemented strategically is believing to be able to improve students' higher-order thinking skills.

Learning Methods CTL is a studentcentered or student-centered approach, so students can actively engage by asking and helping to relate the material given to real life. This will be different if the lecturer acts as a knowledge center for students. The role of more students as the recipient of the concept that the lecturer to convey

\section{CONCLUSION}

Based on the results of research and discussion of the data, obtained the following conclusions:

1. Learning outcomes with Contextual Teaching Learning (CTL) method are variant coevisient pre $=60.23$, standard deviation $=7.76$, mean value $=34.33$, post test value, variant coefficient $=18.57$, standard deviation $=4,31$, mean $=71.00$.

2. Learning outcomes with Problem Based Learning (PBL) method are pre test, coefficient of variance $=51.67$, standard deviation $=7.18$, mean $=38.67$, post test value, variant coefficient $=40$, standard deviation $=6.32$, mean $=81.00$.

3. In CTL learning method, the students' understanding level is a medium category and PBL learning method is the high category, especially on caput suksedaneum, cephal hematoma and hypothermi sub subject.

4. CTL learning method has the effectiveness of 36.67 and PBL learning method has effectiveness 42,32 on caput suksedaneum, cephal hematoma, and hypothermi sub subject.

5. In terms of learning process, PBL learning method is very effective $80 \%$ in increasing student activity compared to CTL method, which is effective only $60 \%$ in increasing student activity.

6. The classical completeness of CTL learning method with sub subjects of caput succedaneum, cephalic hematoma and hypothermia are $73 \% \leq 85 \%$ with Graduated Boundary (NBL) score is 69 .

7. The classical completeness of PBL learning method with sub subject of succedaneum, cephalic hematoma and hypothermia are $100 \%>85 \%$ with Graduated Boundary Value (NBL) is 69. 


\section{REFERENCES}

[1]. Peraturan Presiden Republik Indonesia Nomor 8 Tahun 2012 tentang Kerangka Kualifikasi Nasional Indonesia, Jakarta, 2012.

[2]. Permenristekdikti Nomor 44 tahun 2015 tentang Standar Nasional Pendidikan Tinggi, Jakarta, 2015.

[3]. Priansa, Donni Juni. Manajemen Peserta Didik dan Model Pembelajaran. Alfabeta, Bandung: 2015.

[4]. Desi Kumala F. P. Aplikasi Metode Pembelajaran Kooperatif Model ThinkPair Share Terhadap Hasil Belajar Mata Kuliah Kesehatan Reproduksi Pada Mahasiswa Prodi DIII Kebidanan STIKES Eka Harap Palangkaraya. <Skripsi>. STIKES Sari Mulia, Banjarmasin, 2012.

[5]. Emzir. Metodologi Penelitian

Pendidikan: Kuantitatif dan Kualitatif. Jakarta: Rajawali Pers. 2013

[6]. Amrizaldi. Pengaruh Pembelajaran Melalui Pendekatan Contextual Teaching Learning Terhadap Hasil Belajar Siswa. <Skripsi>. Jakarta. UIN Syarif Hidayatullah. 2010.

[7]. Heojeong Yoon., Ae Ja Woo., David F. Treagust., A. L. Chandrasegaran, SecondYear College Students' Scientific Attitudes and Creative Thinking Ability: Influence of a Problem-Based Learning (PBL) Chemistry Laboratory Course. Affective Dimensions in Chemistry Education. 2015.

[8]. Neni Widiastuti. Pembelajaran Matematika Menggunakan Contextual Teaching And Learning (CTL) Dan Problem Based Learning (PBL) Ditinjau Dari Kemampuan Memori Siswa Pada Pokok Bahasan Kubus dan Balok.
Jurnal Akademis dan Gagasan Matematika. 2015. 2(24-36)

[9]. Kokom Komalasari. The Effect Of Contextual Learning In Civic Education On Students' Character Development. Asia Pacific Journal of Educators and Education. 2012. 27. 87-103

[10]. Kye Mon Min Swe., Amit Bhardwaj., Kavitha Nagandla., Adinegara Bin Lutfi Abas., Nimal Kumar Sinha. The Perception and Usefulness of Problem Based Learning Among Medical Students. iMedPub Journal. 2015. 8(229)

[11]. Mikkelsen JM, Holm HA. Contextual Learning to Improve Health Care and Patient Safety. Education for Health. 2007. 20(3)

[12]. Amina M R EL-Nemer., Soo Downe., Nabeel Joseph Awadalla. The Impact of Problem Based learning Module on Maternity Nursing Students' Experiences and Achievements. High Institute of Public Health. .2009., 39(1)

[13]. Katherine Camacho Carr CNM, PhD. Using the Unfolding Case Study in Midwifery Education. Journal of Midwifery \& Women's Health. 2015.60(3)

[14]. Brett Williams. Qualitative Analysis of Undergraduate Paramedic Students' Perceptions of Using Case-Based Learning in an Online Learning Environment. Journal of Emergency Primary Health Care (JEPHC). 2006.

[15]. Latifah Abdul Raub., Nurbiha A. Shukor., Mohammad Yusof Arshad., \& Mohd hafie Rosli. An Integrated Model to Implement Contextual Learning with Virtual Learning Environment for Promoting Higher Order Thinking Skills in Malaysian Secondary Schools. International Education Studies. 2015.8(13). 